\title{
Comparison of two point abundance sampling methods to assess young roach (Rutilus rutilus L.) microhabitat in the littoral zone of lake Pareloup (France)
}

\author{
S. Brosse $e^{1,2}$ \\ S. Gabas ${ }^{1}$ \\ K. Cever ${ }^{1}$ \\ S. Lek ${ }^{1}$
}

Keywords : sampling methods, point abundance sampling, electrofishing, scuba diving, lake, roach.

One of the most frequently used sampling methods used in defining fish microhabitat is the Point Abundance Sampling by Electrofishing (PASE) technique. Nevertheless this method is size-selective and induces escapement behaviour in most fish species. The aim of this study is first to describe a direct visual fish observation method, the Point Abundance Sampling by Scuba diving (PASS), and second, to compare this method with the classical PASE to determine 0+ (i.e. young of the year) roach (Rutilus rutilus. L.) microhabitat in the littoral zone of a mesotrophic lake.

The study was undertaken during summer 1998 in lake Pareloup (south-west France). Sampling was performed weekly in two restricted littoral areas of the lake which presented the same environmental and topographical characteristics aiming to compare 0+ roach habitat features obtained using the two sampling techniques (PASE and PASS). The two data matrices obtained (i.e. PASE and PASS) were used to develop microhabitat preference indices for each of the 9 variables as a measurement of habitat use by the $0+$ roach vs. habitat availability.

Even though $0+$ roach occurrence and abundance were found to be similar with both methods, microhabitat profiles revealed different patterns. A significant microhabitat difference between the two sampling methods was found using the non-parametric statistical test of Wilcoxon $(Z=-4.20, p<0.01)$. We can hypothesise that the differences observed between the two sampling designs were due to an escapement behaviour of 0+ roach. Unlike PASS, using PASE, fish are located in «shelter habitats» such as shallow water and dense vegetation. Such behaviour is caused by the environmental disturbance induced by this sampling method. The study reveals that PASS appears to be more suitable than PASE for the assessment 0+ fish microhabitat.

Comparaison de deux méthodes d'échantillonnage ponctuel d'abondance pour l'estimation du microhabitat du jeune gardon (Rutilus rutilus L.) en zone littorale du lac de Pareloup (France)

Mots-clés : méthodes d'échantillonnage, échantillonnage ponctuel d'abondance, pêche électrique, plongée sous marine, lac, gardon.

L'une des méthodes les plus fréquemment utilisées pour définir le microhabitat des poissons est la technique d'échantillonnage ponctuel d'abondance par pêche électrique (PASE). Cependant, cette méthode s'avère sélective au niveau de la taille et induit un comportement d'échappement pour de nombreuses espèces. Le but de cette étude est d'abord de décrire une méthode d'observation visuelle directe des poissons, l'échantillonnage ponctuel d'abondance par plongée (PASS) et ensuite de comparer son efficacité à celle de PASE pour déterminer le microhabitat des jeunes $(0+)$ gardons (Rutilus rutilus L.) en zone littorale d'un lac mésotrophe.

L'étude a été menée durant l'été 1998 dans le lac de Pareloup (France). L'échantillonnage a été réalisé dans deux zones littorales du lac présentant les mêmes caractéristiques environnementales de manière à comparer l'habitat obtenu avec chacune des deux techniques d'échantillonnage (PASE et PASS). Les deux matrices de données (PASE et PASS) ont été utilisées pour développer des indices de préférence du microhabitat pour chacune des 9 variables environnementales prises en compte.

1. Centre d'Ecologie des Systèmes Aquatiques Continentaux, UMR C 5576, CNRS, Université Paul Sabatier, 118 Route dé Narbonne, F-31062 Toulouse Cedex 04, France.

2. Corresponding author: Fax (33) 5615560 96, E-mail: brosse@cict.fr 
Alors que les deux méthodes donnent des valeurs identiques d'occurrence et d'abondance des gardons 0+, les profils de microhabitat révèlent des tendances différentes. En effet, une différence significative entre les profils obtenus par chacune des deux méthodes est révélée par le test non-paramétrique de Wilcoxon. Nous pouvons formuler l'hypothèse que les différences observées sont dues à un comportement de fuite du gardon $0+$ face à l'une des méthodes d'échantillonnage. Contrairement aux résultats obtenus par PASS, par PASE, les poissons sont localisés dans des «habitats refuges», tels que les eaux peu profondes ou couvertes d'une dense végétation aquatique, conséquents d'une perturbation environnementale causée par cette méthode d'échantillonnage. Cette étude révèle que la méthode PASS semble mieux adaptée que celle de PASE concernant l'estimation du microhabitat des jeunes poissons.

\section{Introduction}

The spatial distribution of organisms in ecosystems is of crucial importance in understanding ecosystem functioning (Rosenzweig 1991, Hayes et al. 1996). For several years, increasing interest has been taken in the study of the spatial distribution of lake fish populations (Bohl 1980, Imbrock et al. 1996). In European rivers, some studies have focused on fish microhabitat by taking into account several environmental variables (Nelva et al. 1979, Copp 1993). More recently, microand meso-scale habitat studies have been extended to lakes (Rossier 1995, Fisher \& Eckmann 1997, Brosse et al. 1999a).

One of the most frequently used sampling methods to define fish microhabitat is the Point Abundance Sampling by Electrofishing (PASE) technique (Nelva et al. 1979). Nevertheless this method is known to be size-selective and induces fish escapement behaviour.

Direct sampling methods, such as diving were primarily applied in marine waters (Brock 1954). These methods were also employed in North American streams to study salmonid behaviour (Ellis 1961, Keenleyside 1962) and microhabitat (Beecher et al. 1993). Nevertheless, scuba diving has been poorly used in lakes. In Europe, the work of Rossier (1995) is probably the first habitat study based on diving in a lake, but the study was on a large geographic scale and microhabitat was not taken into account. To address this deficiency, we have developed a direct visual fish observation method, Point Abundance Sampling by Scuba (PASS) applied in the littoral zone of a lake to study fish populations on the microhabitat scale.

The goal of the study is first to set up and validate the technique by defining precisely young of the year $(0+)$ roach (Rutilus rutilus $\mathrm{L}$.) microhabitat during the summer period, and second, to compare its efficiency with classical PASE to determine $0+$ roach microhabitat in the littoral zone of a mesotrophic lake.

\section{Material and methods}

The study was undertaken during summer 1998 in lake Pareloup. This reservoir is located in the southwest of France, near the city of Rodez (Fig.1). It covers a total area of 1250 ha for a volume of about $168 \times 10^{6}$ $\mathrm{m}^{3}$. The maximum depth is $37 \mathrm{~m}$ and the average depth is $12.5 \mathrm{~m}$. Lake Pareloup is a warm monomictic la$\mathrm{ke}$, which is submitted to summer thermal stratification with low oxygen content below the thermocline (located about $10 \mathrm{~m}$ below the surface from early June to mid-September) which prevents the fish from colonising deep water during this period (Richeux et al. 1994, Brosse et al. 1999c).

In order to obtain comparable samples we chose two restricted areas of the lake which present the same environmental and topographical characteristics in order to compare the assessment of $0+$ roach microhabitat using the two sampling techniques: PASE in the first bay and PASS in the other one (Fig.1). The two areas within the lake were chosen for their topographical heterogeneity providing numerous kinds of habitats. Both fish sampling techniques were performed weekly from spawning (late May) to the juvenile period (late August) in the littoral zone of the lake (i.e. 12 weeks).

The point abundance sampling method, originally developed by Blondel et al. (1970), is intended for clumped distribution, and based on the statistical theory that many small sample units provide more precise results than a few large samples. On the basis of this theory, two sampling methods could be used :

i) Point Abundance Sampling by Electrofishing (PASE) (Nelva et al. 1979) modified for young fish (Copp 1989) was employed to evaluate the 0+ roach microhabitat. Fishes were collected using a backpack electroshocker fitted with a small $10 \mathrm{~cm}$ ring anode. This method provides reproducible and quantifiable point samples, and it is efficient for the entire range of $0+\mathrm{fi}-$ sh sizes (Copp 1989). The sampling technique consists of a discreet approach on foot to the randomly chosen 


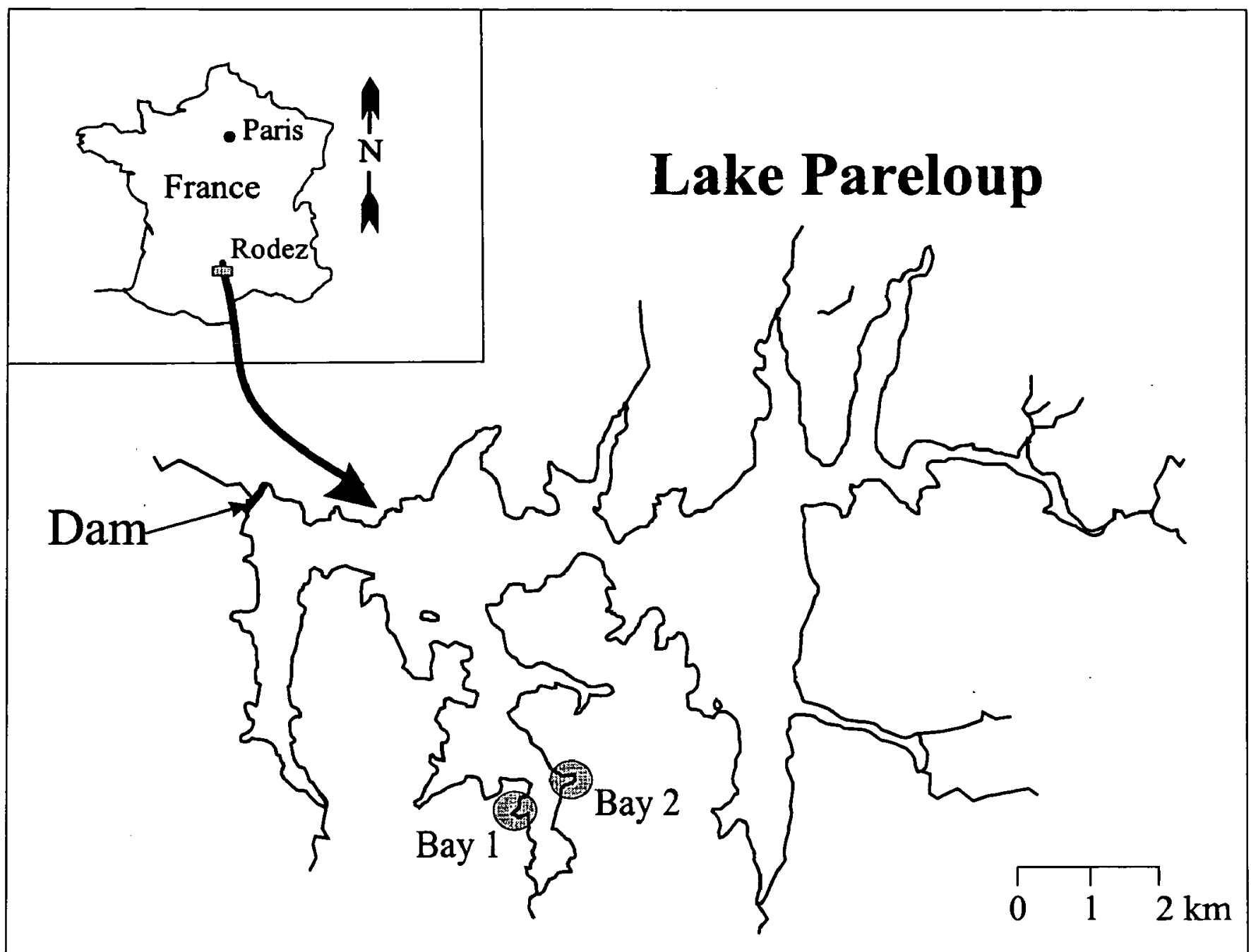

Fig. 1. Map of Lake Pareloup and location of the two different sampling sites : Bay 1 : Point Abundance Sampling by Electrofishing (PASE) and Bay 2 : Point Abundance Sampling by Scuba (PASS).

Fig. 1. Carte du Lac de Pareloup, et localisation des deux sites d'échantillonnage : Bay 1 : PASE et Bay 2 : PASS.

point. The use of a rubber rowing dinghy was dropped because of its inability to sample shallow, gently slopping, muddy areas with this method. Upon arrival at the chosen point, the anode was swiftly immersed about $0.5 \mathrm{~m}$ into the water and any shocked fish were then collected with a fine-mesh dipnet. 120 to 150 points were sampled weekly. The specimens were preserved in $4 \%$ formaldehyde and 9 environmental variables were measured in order to assess $0+$ roach microhabitat : distance from the bank, depth, flooded vegetation cover, percentage of boulders, pebbles, gravel, sand, silt and mud. This sampling design requires the presence of three people : the first with the electroshocker, the second with the dipnet and a third on the bank to note the results.

ii) We developed Point Abundance Sampling by Scuba diving (PASS) to perform the same type of analysis. 11 transects were defined. Their lengths depend on the depth and varied between 4 and $32 \mathrm{~m}$. Each transect was defined by a 2-m-wide observation lane from the bank down to $1.2 \mathrm{~m}$ depth marked off every $1 \mathrm{~m}$. This gave 201 sampling points. For each sampling point, 9 environmental parameters were measured at the beginning of the sampling period (i.e. late May). These measurements were repeated once a month and more frequently when environmental changes such as water weed growth or water level fluctuations occurred. Every week, the snorkeled observer swam in each lane, covering the full area of each point. Water clarity was sufficient to determine and count all the fish for each 2-m-wide and 1-m-long point. When dense fish shoals were observed, counting was limited to a subsample, and then extrapolated over the entire surface of the sample. This sampling design required the presence of only one person, who noted all the information on a waterproof board.

The data matrices obtained using the two techniques (i.e. PASE and PASS) were used to develop microhabi- 
tat preference indices for each of the 9 variables as a measurement of habitat use by the $0+$ roach vs. habitat availability. Preference was calculated as a normalised ratio of utilisation to availability for different intervals of each environmental variable, based on the method of Beecher et al. (1993). Preference indices were obtained after dividing each variable into several segments. Their number was defined according to the range of variation of each variable. The following formula was used :

$$
I=(\mathrm{Ob} / \mathrm{Ex}) /(\mathrm{Ob} / \mathrm{Ex})_{\max }-0.5
$$

Where $\mathrm{Ob}$ is the number of roach observed in that segment, Ex is the expected number of roach for a theoretical random distribution, $(\mathrm{Ob} / \mathrm{Ex})_{\max }$ is the maximum value of $(\mathrm{Ob} / \mathrm{Ex})$ for the segment. $I$ varies between -0.5 and +0.5 ; values between -0.5 and 0 reveal an avoidance, between 0 and +0.5 a preference and values close to 0 can be considered as revealing indifference.

To estimate any significant difference between the two methods (PASE and PASS), we used the Wilcoxon non-parametric test to compare the two paired groups to know if their difference is significantly different from a null value. This test was computed using SPSS release 8 for Windows.

\section{Results}

Within the whole data matrix, i.e. 2412 sample points, $0+$ roach were present in $23 \%$ of the samples using PASE and in $19 \%$ using PASS. Among the entire fish community, $0+$ roach represented $48 \%$ of the recorded fish using PASE and $51 \%$ using PASS. As a consequence, the relative occurrence and abundance of $0+$ roach revealed almost the same results between both sampling methods.

Concerning microhabitat studies, the Pearson correlation matrix showed a strong correlation between the variables silt and sand ( -0.62 for PASE and -0.86 for PASS) and between silt and vegetation cover ( -0.75 for PASE and -0.66 for PASS). So, to avoid colinearity between variables, the percentage of silt was removed from the two data matrices. Thus, all the statistical analyses were performed on a set of eight variables (distance from the bank, depth, percentage of mud, sand, gravel, pebbles, boulders, and flooded vegetation cover).

$0+$ roach microhabitat profiles assessed using the two sampling methods revealed differences in the patterns reinforced by the non-parametric statistical test of Wilcoxon which showed a significant difference between the two methods $(Z=-4.20, p<0.01)$. Using electrofishing, $0+$ roach was found to live close to the bank, generally avoiding distances from the bank over $5 \mathrm{~m}$ (Fig. 2a). With PASS, roach were observed at distance further from the bank $(5-10 \mathrm{~m})$, but they avoided distances over $15 \mathrm{~m}$ (Fig. 2b). The results performed by PASE showed that roach also avoided deep water (more than $0.5 \mathrm{~m}$ ), whereas with scuba diving, roach were observed at depths of over $0.5 \mathrm{~m}$. Muddy substrata are avoided with PASS whereas roach collected with PASE were found on mud. In the same way, gravel was found as being preferred by PASS and avoided by PASE. Finally, considering flooded vegetation cover, PASS revealed a preference for intermediate vegetation cover (i.e. 25-75\%), whereas PASE revealed a preference for dense cover.

\section{Discussion}

The relative occurrence and abundance of roach observed showed that both methods are able to reliably sample $0+$ roach in the littoral zone of lake Pareloup, which sustains high fish abundance during the summer (Brosse et al. 1999a,b). Nevertheless, at the microhabitat scale, differences were recorded between the two methods. Using PASE, fish were located in «shelter habitats» such as shallow water and dense vegetation. Such habitat use was probably induced by the environmental disturbance caused by the observers. On the contrary, habitat features obtained with PASS were in accordance with previous studies revealing on the one hand that $0+$ roach feeding efficiency is maximum in low vegetation density and open water (Persson 1993, Eklöv \& Persson 1996) and on the other hand, that the spatial occupancy of $0+$ roach located close to shelters (i.e. flooded vegetation) can be related to predation avoidance of adult perch (Perca fluviatilis L.) and $0+$ pike (Esox lucius L.) (Mittelbach 1981, Persson \& Greenberg 1990, Eklöv \& Diehl 1994, Eklöv \& Persson 1995). Using PASE, 0+ roach were mainly found in highly vegetated areas located close to the bank, in very shallow water; these microhabitat features can be attributed to escapement from observer stamping around. This hypothesis is reinforced by the study of substrate occupancy; using electrofishing, $0+$ roach were found in muddy substrata which is unusual as mud does not constitute a food item for $0+$ roach (Dubois et al. 1994, Angelibert et al. 1999). On the contrary, according to PASS results, this species is usually strongly associated with medium depths (c.a. $0.75 \mathrm{~m}$ ) and sandy substrata (Copp 1990).

In the littoral zone of lake Pareloup, the results given by PASE reveal a $0+$ roach microhabitat use influenced by observer disturbance. This technique does not re- 


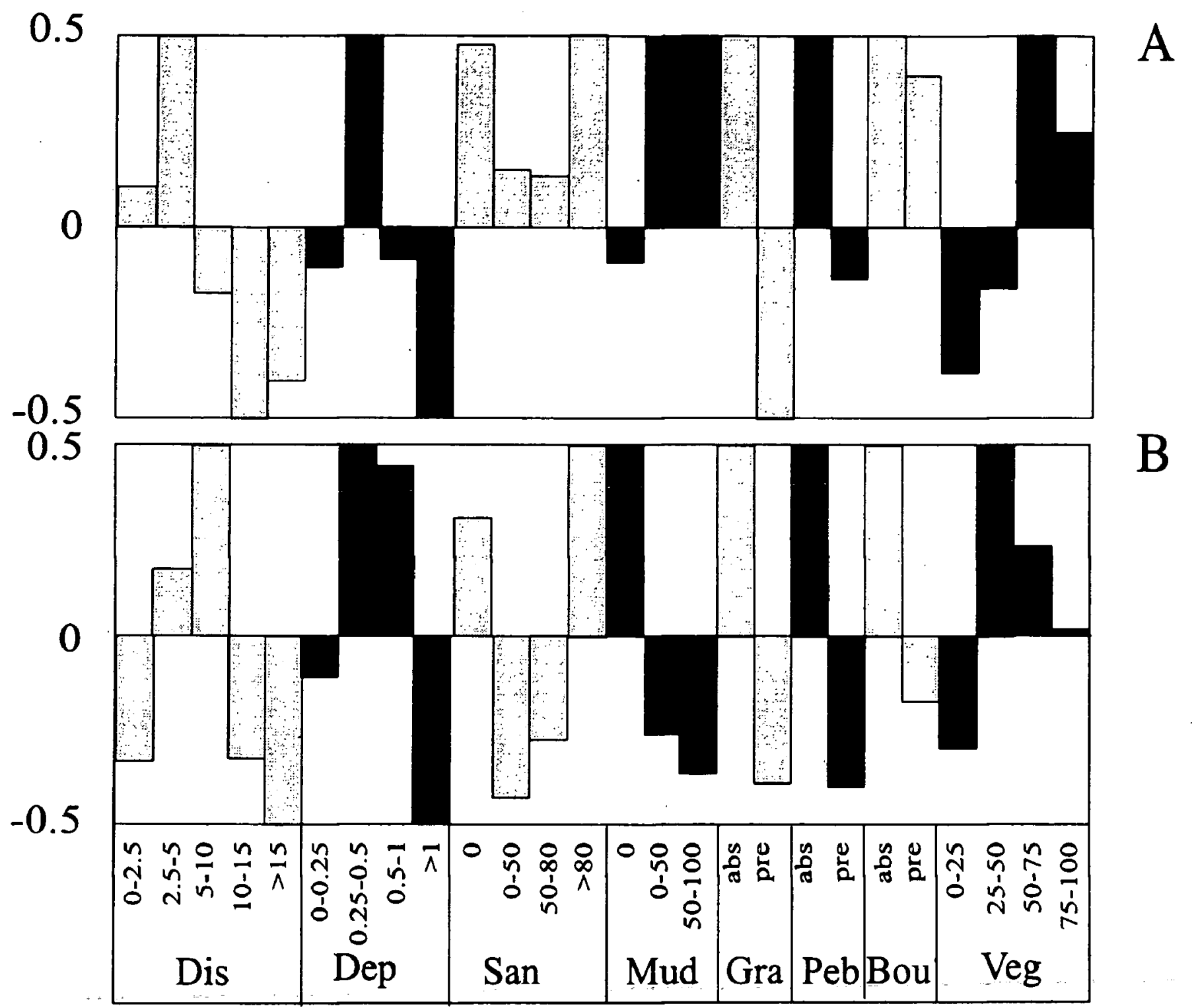

Fig. 2. Environmental profile of $0+$ roach calculated for the eight environmental variables, each divided into a limited number of segments, using the two sampling techniques. A : PASE, B : PASS. Dis : distance from the bank, Dep : depth, San : sand, Mud : mud, Gra : gravel, Peb : pebbles, Bou : boulders, Veg : flooded vegetation ; pres : presence, abs : absence.

Fig. 2. Profil d'habitat du jeune gardon en fonction des huit variables environnementales étudiées (voir le texte pour les détails) en utilisant chacune des deux méthodes d'échantillonnage. A : PASE, B : PASS. Dis : distance à la berge, Dep : profondeur, San : sable, Mud : vase, Gra : graviers, Peb : galets, Bou : blocs, Veg : couverture en macrophytes ; pres : présence, abs : absence.

veal the entire range of $0+$ roach microhabitat, but essentially one part of it, corresponding to the shelter habitat. Nevertheless electrofishing can be used in a wider range of situations than PASS, and is less affected by turbidity and wind-induced waves which make visual observations impossible. Moreover, PASE permits fish to be captured and thus the number and developmental stage or length of each individual to be determined accurately. However, this catching method might damage the littoral habitat by the observer stamping around and destroying the substratum and the vegetation cover (Hammer 1985) and thus modifying the environmental components leading to biases when repeated samples are made during a short period. Using PASS, fish escapement behaviour was very rarely observed. Moreover, this method prevents the substratum from being damaged and does not affect the welfare of the fish. This study indicates that PASS seems better suited to determine $0+$ fish microhabitat in the littoral areas of lakes than indirect sampling designs such as PASE because of the accuracy of the results provided and the avoidance of physically disturbing the assemblage. 


\section{References}

Angelibert S., Brosse S., Dauba F. \& Lek S. 1999. - Changes in roach (Rutilus rutilus $\mathrm{L}$.) population structure induced on draining a large reservoir. C. R. Acad. Sci. III Paris, 322 : 331-338.

Beecher H.A., Johnson T.H. \& Carleton J.P. 1993. — Predicting microdistributions of steelhead (Oncorhynchus mykiss) parr from depth and velocity preference criteria : test of an assumption of the instream flow incremental methodology. Can. J. Fish. Aquat. Sci., $50: 1380-1387$.

Blondel J., Ferry C. \& Frochot B. 1970. — La méthode des indices ponctuels d'abondance (IPA) ou des relevés d'avifaune par «stations d'écoute». Alauda, $38:$ 55-71.

Bohl E. 1980. - Diel pattern of pelagic distribution and feeding in planktivorous fish. Oecologia, 44 : 368-375.

Brock V. 1954. - A preliminary report on a method of estimating reef fish populations. J. Wildlife. Manage., 18 : 297-308.

Brosse S., Guéguan J.F., Tourenq J.N. \& Lek S. 1999a. - The use of artificial neural networks to assess fish community structure in the littoral zone of a mesotrophic lake. Ecol. Model., (in press).

Brosse S., Dauba F., Oberdorff T. \& Lek S. 1999b. - Influence of some topographical variables on the spatial distribution of lake fish during summer stratification. Arch. Hydrobiol., 145 : 359-371.

Brosse S., Lek S. \& Dauba F. 1999c. - Predicting fish distribution in a mesotrophic lake by hydroaccoustic survey and artificial neural networks. Limnol. Oceanogr., 44 : 1293-1303.

Copp G.H. 1989. - Electrofishing for fish larvae and juveniles : equipment modifications for increased efficiency with short fishes. Aquacult. Fish. Manage., $20:$ 453-462.

Copp G.H. 1990. - Shifts in the microhabitat of larval and juvenile roach, Rutilus rutilus $\mathrm{L}$. in a floodplain channel. J. Fish Biol., 36 : 683-692.

Copp G.H. 1993. - Microhabitat use of fish larvae and 0+ juveniles in a small abandonned channel of the upper river Rhône, France. Folia Zool., 42 : 153-164.

Dubois C., Richeux C., Tourenq J.N. \& Lejolivet C. 1994. - Régime et comportement alimentaire du gardon (Rutilus rutilus $\mathrm{L}$.) et de la perche (Perca fluviatilis $\mathrm{L}$.) de la retenue de Pareloup. I. Les alevins. Hydroécol. Appl., 6 : 227-242.

Eklöv P. \& Diehl S. 1994. - Piscivore efficiency and refuging prey : the importance of predator search mode. Oecologia, $98: 344-353$.

Eklöv P. \& Persson L. 1995. - Species-specific antipredator capacities and prey refuges : interactions between piscivorous perch, (Perca fluviatilis), and juvenile perch and roach, (Rutilus rutilus). Behav. Ecol. Sociobiol., 37 : 169-178.
Eklöv P. \& Persson L. 1996. - The response of prey to the risk of predation : proximate cues for refuging juvenile fish. Anim. Behav., 51 : 105-115.

Ellis D.V. 1961. - Diving and photographic techniques for observing and recording salmon activities. J. Fish. Res. Board. Can., $18: 1159-1166$.

Fischer P. \& Eckmann R. 1997. - Spatial distribution of littoral fish species in a large European lake, Lake Constance, Germany. Arch. Hydrobiol., $140: 91-116$.

Hammer C. 1985. - Feeding behaviour of roach (Rutilus rutilus) larvae and the fry of perch (Perca fluviatilis) in Lake Lankau. Arch. Hydrobiol., 103 : 61-74.

Hayes D.B., Ferreri C.P. \& Taylor W.W. 1996. — Linking fish habitat to their population dynamics. Can. J. Fish. Aquat. Sci., 53 : 383-390.

Imbrock F., Appenzeller A. \& Eckmann R. 1996. — Diel and seasonal distribution of perch in Lake Constance : a hydroacoustic study and in situ observations. J. Fish Biol., 49 : 1-13.

Keenleyside M.H.A. 1962. - Skin-diving observations of Atlantis salmon and brook trout in the Miramichi River, New Brunswick. J. Fish. Res. Board. Can., $19: 625-634$.

Mittelbach G.G. 1981. — Foraging efficiency and body size : a study of optimal diet and habitat use by bluegills. Ecology, 62 : 1370-1386.

Nelva A., Persat H. \& Chessel D. 1979. - Une nouvelle méthode d'étude des peuplements ichtyologiques dans les grands cours d'eau par échantillonnage ponctuel d'abondance. C. R. Acad. Sci. III Paris, 289 : 1295-1298.

Persson L. 1993. - Predator-mediated competition in prey refuges : the importance of habitat dependent prey resources. Oikos, 68 : $12-22$.

Persson L. \& Greenberg L.A. 1990. - Juvenile competitive bottlenecks : the perch (Perca fluviatilis)-roach (Rutilus rutilus) interaction. Ecology, 71 : 44-56.

Richeux C., Nogues J.F., Tourenq J.N. \& Aragon B. 1994. - Inventaire piscicole de la retenue hydroéléctrique de Pareloup (Aveyron, France) lors de la vidange de Juin 1993. Essai d'un nouveau système d'acquisition et de traitement des signaux d'un échosondeur. Hydroécol. Appl., 6 : 197-226.

Rosenzweig M.L. 1991. - Habitat selection and populations interactions : the search for mechanisms. Am. Nat., $137: 5-28$

Rossier O. 1995. - Spatial and temporal separation of littoral zone fishes of Lake Geneva (Switzerland - France). Hydrobiologia 300/301 : 321-327. 